\title{
Apresentação
}

\section{Uma apresentação e mais: um nascimento}

\author{
Ana Elisa Ribeiro'(1) \\ 'Centro Federal de Educação Tecnológica de Minas Gerais, Departamento de Linguagem e Tecnologia, \\ Belo Horizonte, MG, Brasil
}

Para uma parte da humanidade que se interessa profundamente pelos livros, pela leitura, pela escrita e pelos processos editoriais, não é preciso explicar por que razão uma revista como a Gutenberg nasce sob este nome. É com imensa alegria que apresento este primeiro número, composto por textos de pesquisadores e pesquisadoras brasileiros e estrangeiros que, tenho certeza, assim como eu, ansiavam por uma publicação explicitamente dedicada à produção editorial, sem subterfúgios, sem distorções, sem acomodações um pouco incômodas. Meu agradecimento à professora Cláudia Bomfá e a toda a equipe da revista na Universidade Federal de Santa Maria é tão eterno quanto minha sensação de que teremos, de agora em diante, certa sensação de "amadrinhamento" em relação a este periódico, que nasce inclusive meio gêmeo de outro, que vimos desenvolvendo no CEFET-MG. De modo semelhante, gêmeos são nossos cursos, nossas pesquisas e nossos compromissos com a área, explicitados, há mais de uma década, na colaboração efetiva que sempre fizemos questão de manter. É com respeito, alegria, gratidão e sentindo-me honrada que apresento este primeiro número da revista Gutenberg.

Este periódico científico, que nasce num solo fértil de colaboração e afeto, mas também criterioso e cuidadoso, faz sua estreia com um conjunto de dez textos, entre artigos, ensaios e uma resenha. Nessa diversidade de gêneros discursivos também é 
possível entrever a diversidade de instituições, geografias e pesquisadores/as que se dedicam a aspectos sortidos da edição, do livro e da leitura.

Com enorme honra, o número 1 do primeiro volume da revista Gutenberg conta com o texto "Eran estos libros no como los nuestros': crónicas de un encuentro bibliográfico entre dos mundos", da professora e pesquisadora argentino-mexicana Marina Garone Gravier, do Instituto de Investigaciones Bibliográficas da Universidad Nacional Autónoma de México (UNAM), com quem vimos trocando e aprendendo há vários anos. No artigo, ela tenta precisar as características do que se compreendia por "livro e escrita" "durante os processos culturais, políticos e sociais da conquista da América", sob o olhar estrangeiro, que contrapôs o alfabeto latino e o livro europeu às estruturas, aos suportes e aos sistemas de notação indígenas. Tal "intercâmbio cultural" é de grande importância para o México, mas também para todos nós que passamos por regimes e processos de colonização. O texto é aqui publicado em sua língua original, numa demonstração de abertura e receptividade deste periódico científico que nasce sob o signo das trocas predispostas à intercompreensão.

Na sequência, a professora e pesquisadora argentina Magdalena González Almada (CIFFyH-CONICET, Universidad Nacional de Córdoba), também editora, nos presenteia com o texto "La literatura y sus tramas: panorama contemporáneo de la edición literaria en Bolivia", no qual apresenta uma cartografia editorial da Bolívia. Trata-se de um trabalho não exaustivo, mas muito esclarecedor, que nos põe em contato com o país vizinho andino-amazônico que pouco conhecemos. Por lá, ao que parece, as pessoas também têm atuado no duplo papel de escritoras e editoras.

Entre as pesquisadoras brasileiras que compõem este primeiro número está a professora Livia Salles, do Departamento de Comunicação Social da PUC-Rio, com o artigo "A presença social do livro: cultura material e público juvenil", em que ela investiga a importância da materialidade do livro para esse público. Por meio de um desenho metodológico de cunho qualitativo, jovens leitoras puderam expressar sua relação com livros e leituras, questão também de pertencimento e identidade. Mantendo o foco nos jovens, o professor Marcelo Amaral Moraes, doutorando do 
Programa de Pós-Graduação em Estudos de Linguagens do Centro Federal de Educação Tecnológica de Minas Gerais (CEFET-MG), apresenta resultados de uma investigação que tomou como corpus best-sellers infantojuvenis. No artigo intitulado "Leiam meninos: Uma análise das materialidades do livro e do conteúdo dos bestsellers para crianças e pré-adolescentes do sexo masculino, entre 8 e 12 anos", Moraes procurar distinguir "quais são os elementos editoriais que potencialmente contribuem para o sucesso editorial de um livro para meninos" nessa faixa etária. A pretensão do artigo é contribuir para uma melhor compreensão do que deseja ler esse público e subsidiar a curadoria de títulos no mercado editorial nacional.

Em "Edições de literatura indígena no Brasil: visibilidades e opacidades", a pesquisadora Marta A. P. da Rocha Costa, mestra em Estudos de Linguagens pelo Centro Federal de Educação Tecnológica de Minas Gerais (CEFET-MG), se dedica a dois livros publicados no Brasil. O objetivo da investigação relatada foi observar se tais obras seriam percebidas por leitores como de autoria indígena e se "teriam alguma visibilidade questões como gênero e autoria", por meio dos projetos editoriais e gráficos. Grupos de estudantes receberam essas edições para manusear, analisar paratextos e registrar suas percepções por escrito. Desses registros saem as notas de Rocha Costa, que conclui que tais livros não foram percebidos como de autoria indígena, ao menos por meio de suas materialidades.

Para tratar, agora, do ponto de vista do editor, Leonardo Morais, do CEFET-MG, em "Massao Ohno: editor independente?", se dedica à trajetória desse editor que atuou em São Paulo. Voltada predominantemente para a publicação de literatura, especialmente a poesia, Massao selecionava, editava e era o designer da maioria absoluta dos livros que publicava. Morais propõe pensar se ou como a editora de Ohno se configuraria em relação ao que se tem chamado hoje de "independência".

Dando prosseguimento ao nosso número inaugural, dois textos focalizam uma etapa sempre fulcral e nem sempre visibilizada da produção editorial: a revisão de textos. Em "A revisão de textos nos ritos genéticos editoriais", uma das maiores especialistas do país, a professora Luciana Salazar Salgado, do Departamento de Letras 
da Universidade Federal de São Carlos (UFSCar), aborda e detalha as "bases discursivas da noção de 'ritos genéticos editoriais"' e daí desdobra conceitos como "código linguageiro", "regimes de genericidade" e "ethos discursivo". A partir disso, a autora analisa materiais revisados e ilumina o ofício de revisar textos, de algum modo também sugerindo um método de trabalho, pesquisa e formação para revisores e revisoras.

De outro ângulo, mas também com as luzes sobre a revisão textual em contexto editorial, a convite da editoria deste periódico que se inaugura, tive a honra de apresentar meu ensaio "Outras margens da revisão de textos: experiências com o literário", em que abordo alguns saberes e práticas mais específicos da revisão do texto literário, com breve discussão de casos empíricos de revisão de textos literários contemporâneos. Este é um dos temas a que me dedico há muitos anos, profissional e academicamente, e é uma honra colaborar com a revista Gutenberg com este assunto. Neste texto, como pesquisadora do Programa de Pós-Graduação em Estudos de Linguagens do Centro Federal de Educação Tecnológica de Minas Gerais (CEFET-MG) e revisora de prosa e verso, defendo a ideia de que "para um texto literário é necessária uma revisão também literária, isto é, uma prática de revisão mais sensível às questões que tocam esta arte, baseadas em decisões prévias ou acordadas diligentemente com editores/as e autores/as".

Outro ensaio que enriquece este primeiro número é o de Tagiane Mai, pesquisadora do Mestrado em Edição de Texto da Faculdade de Ciências Sociais e Humanas da Universidade Nova de Lisboa (Portugal), revisora e preparadora de textos da Editora da Universidade Federal de Santa Maria (UFSM). Mai se dedica a um tema extremamente atual, desenvolvido a partir da questão que já expõe desde o título de seu texto: "Romance de entretenimento no Prêmio Jabuti 2020: inclusão ou exclusão?". Vale ver como e com que argumentos ela responde a essa provocação.

Para encerrar o número inicial desta revista que nasce com viço e frescor, apresentamos a resenha de autoria do pesquisador Mário Vinícius Ribeiro Gonçalves, designer, mestre em Design Gráfico Multimídia pela École Supérieure d'Art des Pyrénées (ESAP-Pau) e pós-graduado (post-master) em Pesquisa Tipográfica no Atelier 
National de Recherche Typographique (ANRT), na França, atualmente doutorando em Estudos de Linguagens no CEFET-MG. Em "Tinha um editor no meio do caminho, de José de Souza Muniz Jr.", Mário Vinícius comenta e aprecia uma obra que existe como um dos volumes da coleção "Questões contemporâneas de edição, preparação e revisão textual", em pleno andamento pela editora mineira Gulliver, no selo Artigo A.

Como se vê nesse elenco de textos submetidos à revista Gutenberg, avaliados por um conselho que pôs a rodar as engrenagens deste periódico, agora lançado, podemos dizer que os estudos de edição, sob diversos aspectos, encontraram lugar acolhedor e adequado a que se dirigir na forma de artigos, ensaios e resenhas. É questão de ouvir o clique.

\section{Ana Elisa Ribeiro}

Doutora em Estudos Linguísticos

https://orcid.org/0000-0002-4422-7480 • anadigitalpro@gmail.com 